\title{
PADAT PENEBARAN OPTIMAL PENDEDERAN BANDENG (Cbanos cbanos) DALAM HAPA DI TAMBAK TANAH GAMBUT
}

\author{
Usman"), Akhmad Mustafa"), Adi Hanafi"), dan Brata Pantjara")
}

\begin{abstract}
ABSTRAK
Penelitian ini bertujuan untuk mendapatkan padat penebaran optimal pada pendederan bandeng dalam tambak tanah gambut.

Padat penebaran yang dicoba adalah 100,200 dan 300 ekor $/ 0,5 \mathrm{~m}^{3}$, dengan sistem hapa dan masing-masing diulang dua kali. Berat awal dan panjang total nener masing-masing adalah 0,01 g dan $16,3 \mathrm{~mm}$. Selama pemeliharaan ( 20 hari), nener diberi pakan remah, tiga kali sehari dengan dosis menurun dari 100 sampai $15 \%$ berat badan per hari. Pergantian air dilakukan setiap 2-3 hari secara gravitasi atau dengan menggunakan pompa.

Hasil penelitian menunjukkan bahwa padat penebaran yang dicoba belum berpengaruh nyata $(P>0,05)$ terhadap pertumbuhan berat mutlak, laju pertumbuhan harian, kelangsungan hidup, produksi biomassa dan rasio konversi pakan. Pada kepadatan 300 ekor/hapa, masih didapatkan pertumbuhan mutlak $0,27 \mathrm{~g}$, laju pertumbuhan harian $18,1 \%$, kelangsungan hidup $94,17 \%$ dan rasio konversi pakan 1,90. Padat penebaran pada pendederan bandeng di tambak tanah gambut masih dapat ditingkatkan.
\end{abstract}

$\begin{array}{ll}\text { ABSTRACT: } & \text { The Optimum Stocking Density of Milkfish (Cbanos cbanos) Nursery Using } \\ \text { Happa in The Peaty Soil Brackishwater Ponds, by Usman, Akbmad Mustafa, Adi } \\ \text { Hanafi and Brata Pantjara }\end{array}$

The experiment was aimed at finding the optimum stocking density of Chanos chanos fry reared in net cage placed in peaty soil pond. The cage of $0.5 \mathrm{~m}^{3}$, was made of polyethylene with meshsize of $0.8 \mathrm{~mm}$ and installed in bamboo frames. The initial weight of the milkfish fry was 0.01 $\mathrm{g}$, and the total length was $16.3 \mathrm{~mm}$. Three different stocking densities applied were 100, 200, and $300 \mathrm{fry} / \mathrm{cage}$. Each treatment was applied in two replicates and raised for 20 days.

The results showed that there were no significant differences $(P>0.05)$ in absolute growth, daily growth rate, survival rate, biomass and feed conversion ratio among the treatments tested. The stocking density of $300 \mathrm{fry} /$ cage produced the following results absolute growth $0.27 \mathrm{~g}$, daily growth rate $18.1 \%$ /day, survival rate $94.17 \%$, biomass $80.35 \mathrm{~g}$, and feed conversion ratio 1.90 .

KEYWORDS: optimum density, milkfish, peaty soil, brackishwater pond

\section{PENDAHULUAN}

Usaha budidaya ikan dan udang di tambak yang berkembang saat ini menyebabkan terjadinya pembukaan hutan mangrove menjadi tambak. Tanah di hutan mangrove umumnya tergolong jenis tanah gambut dengan $\mathrm{pH}$ tanah yang rendah, bahan organik sangat tinggi dan unsur toksik ( $\mathrm{Fe}$ dan $\mathrm{Al}$ ) yang tinggi (Hakim et al., 1986). Kondisi seperti ini tidak cocok bagi pertumbuhan dan kelangsungan hidup udang windu, yang di dalam pemeliharaannya membutuhkan persyaratan bioteknis yang cukup banyak. Hasil penelitian menunjukkan, bahwa tambak tanah gambut umumnya baru dapat meng- 
hasilkan produksi udang windu dengan baik setelah 3-4 tahun pembukaannya, bila selama itu terus dilakukan reklamasi tanah dengan baik. Umumnya petani tambak belum mengetahui permasalahan tanah gambut dengan baik, namun tahun pertama telah dilakukan pemeliharaan udang windu. Hal ini menyebabkan petambak mengalami kegagalan dan kerugian.

Menurut Mustafa et al. (1993), pengaruh pengapuran terhadap $\mathrm{pH}$ tanah gambut paling nyata pada hari ke-15 sesudah pemberian, setelah itu $\mathrm{pH}$ tanah turun kembali sementara $\mathrm{Fe}$ dan $\mathrm{Al}$ tanah gambut berkurang sejak awal pemberian kapur. Untuk pemanfaatan lahan yang memiliki kondisi demikian, maka pendederan nener merupakan salah satu alternatif. Informasi teknik pendederan pada tambak tanah gambut ini belum tersedia, oleh karena itu perlu dilakukan penelitian aspek padat penebaran yang didasari oleh rendahnya daya dukung lingkungan tambak tanah gambut bagi pemeliharaan hewan akuatik.

\section{BAHAN DAN METODE}

Penelitian dilakukan pada tambak tanah gambut dengan luas $500 \mathrm{~m}^{2}$ berlokasi di Kabupaten Bone, Sulawesi Selatan selama 20 hari.

Hewan uji adalah nener bandeng berukuran berat dan panjang total berturut-turut $0,01 \mathrm{~g}$ dan $16,3 \mathrm{~mm}$ yang diperoleh dari hasil penangkapan di perairan Kolaka, Sulawesi Tenggara. Hewan uji ditempatkan dalam hapa yang terbuat dari waring berukuran mata $0,8 \mathrm{~mm}$ dan ditopang dengan kerangka bambu. Setiap hapa bervolume $0,5 \mathrm{~m}^{3}$ dan dipasang $10 \mathrm{~cm}$ di atas pelataran tambak. Perlakuan yang dicobakan adalah perbedaan padat penebaran yaitu: 100,200 , dan 300 ekor $/ 0,5 \mathrm{~m}^{3}$, masing-masing diulang 2 kali. Pergantian air sebanyak $10-25 \%$ dilakukan setiap $2-3$ hari baik secara gravitasi atau dengan menggunakan pompa.

Pakan yang diberikan adalah pakan remah (crumble) yang biasanya digunakan untuk udang windu dengan komposisi nutriea tertera pada Tabel 1. Dosis pakan sebesar $100 \%$ dari berat total diberikan pada awal penelitian dan menurun menjadi $15 \%$ dari berat total pada akhir penelitian. Pakan diberikan 3 kali sehari yaitu pada pukul $08.00,16.00$, dan 20.00 . Pengukuran berat hewan uji dilakukan setiap 5 hari, untuk penyesuaian dosis pakan.

Pengambilan contoh tanah secara komposit pada petakan dilakukan pada awal dan akhir penelitian, sedangkan pengambilan contoh air dilakukan setiap 5 hari, untuk selanjutnya dianalisis di Laboratorium Kimia Balitkanta Maros. Selain itu, setiap hari dilakukan pengukuran kualitas air langsung di lapangan yang meliputi: salinitas, suhu, $\mathrm{pH}$, dan kecerahan. Pengamatan oksigen terlarut dan suhu selama 24 jam (selang 4 jam) dilakukan pada pertengahan penelitian untuk setiap unit hapa. Pengambilan contoh plankton dilakukan pada awal pemeliharaan, sedangkan pengamatan komposisi jenis dan jumlah bakteri dalam air tambak dilakukan pada awal dan akhir penelitian. 
Tabel 1. Komposisi nutriea makanan yang digunakan dalam pendederan bandeng ${ }^{*}$ )

Table 1. Nutrient composition of feed used in milkfish nursery ponds")

\begin{tabular}{l|c}
\hline \hline Komposisi nutriea & Persentase \\
Nutrient composition & Percentage \\
\hline Protein (Protein) & 38,71 \\
Lemak (Lipid) & 6,44 \\
Abu (Ash) & 10,91 \\
Serat kasar (Crude fiber) & 1,40 \\
Air (Water) & 3,60 \\
Nitrogen-free extract & 38,94 \\
\hline \hline
\end{tabular}

Pertumbuhan berat mutlak dihitung berdasarkan rumus Rounsefell dan Everhart (1962), laju pertumbuhan harian berdasarkan NRC (1977), kelangsungan hidup menurut Ricker (1975), dan rasio konversi pakan berdasarkan Sedgwick (1979), selanjutnya dianalisis ragam dengan menggunakan program MSUSTAT. Sedangkan data kualitas air dan tanah dianalisis secara deskriptif.

\section{HASIL DAN PEMBAHASAN}

\section{Kelangsungan Hidup, Pertumbuhan, dan Rasio Konversi Pakan}

Pendederan benih ikan bandeng pada berbagai padat penebaran dengan sistem hapa dalam tambak tanah gambut baru berpengaruh tidak nyata $(P>0,05)$ terhadap pertumbuhan berat mutlak, laju pertumbuhan harian, kelangsungan hidup, biomassa ikan bandeng, dan rasio konversi pakan (Tabel 2). Hal ini diduga karena padat penebaran yang dicobakan masib sangat rendab (100-300 ekor/hapa), sehingga belum terjadi persaingan baik terhadap ruang maupun makanan. Telah dilaporkan bahwa pada pendederan ikan bandeng dengan sistem hapa $\left(1 \mathrm{~m}^{3}\right)$ di tambak mineral diperoleh kelangsungan hidup antara $62,1-89,3 \%$ pada padat penebaran 2.700 ekor/hapa setelah pemeliharaan 30 hari (Jufri et al., 1994). Begitu pula pendederan pada bak-bak terkontrol yang dilakukan oleh Kahar dan Amin (1988) dengan padat penebaran 200, 300 dan $400 \mathrm{ekor} / \mathrm{m}^{2}$ mendapatkan tingkat kelangsungan hidup yang berbeda tidak nyata, masing-masing $62,5 \%, 90,7 \%$, dan $76,7 \%$ selama pemeliharaan 30 hari. Sedangkan Pongsapan et al. (1995) hanya mendapatkan tingkat kelangsungan hidup 20,0-38,6\% dengan padat penebaran 50 ekor/bak $\left(0,3 \mathrm{~m}^{2}\right)$ selama pemeliharaan 35 hari. 
Tabel 2. Berat mutlak, laju pertumbuhan harian, kelangsungan hidup, biomassa dan rasio konversi pakan benih ikan bandeng pada pendederan dengan padat penebaran yang berbeda di tambak tanah gambut

Table 2. Absolute weight, daily growth rate (DGR), survival rate (SR), biomass, and feed conversion ratio (FCR) of milkfish reared at different stocking densities in peat soil brackishwater pond

\begin{tabular}{|c|c|c|c|c|c|}
\hline $\begin{array}{l}\text { Padat penebaran } \\
\text { (ckor } 10,5 \mathrm{~m}^{3} \text { hapa) } \\
\text { Stocking density } \\
\text { (ind } / 0.5 \mathrm{~m}^{3} \text { cage) }\end{array}$ & $\begin{array}{l}\text { Berat absolut } \\
\text { (g) } \\
\text { Absolute weigbt } \\
(\mathrm{g})\end{array}$ & $\begin{array}{l}\text { DGR } \\
(\%)\end{array}$ & $\begin{array}{l}\text { Kelangsungan } \\
\text { hidup }(\%) \\
\text { Survival rate }(\%)\end{array}$ & $\begin{array}{l}\text { Biomassa (g) } \\
\text { Biomass (g) }\end{array}$ & FCR \\
\hline 100 & $0,510^{2}$ & $21,8^{a}$ & $99,50^{a}$ & $51,65^{a}$ & $1,39^{a}$ \\
\hline 200 & $0,390^{a}$ & $20,2^{a}$ & $92,50^{a}$ & $73,30^{a}$ & $1,64^{a}$ \\
\hline 300 & $0,270^{a}$ & $18,1^{\mathrm{a}}$ & $94,17^{a}$ & $80,35^{a}$ & $1,90^{\mathrm{a}}$ \\
\hline
\end{tabular}

Keterangan: angka rata-rata yang diikuti buruf sama pada kolam yang sama adalab tidak berbeda nyata(P $>0,05)$ Note: mean values in columns followed by similar letter are not significantly different $(P>0.05)$.

Pertumbuhan ikan bandeng yang didapatkan untuk setiap perlakuan masih dalam batas yang normal. Laju pertumbuhan harian pada semua perlakuan masih lebih tinggi daripada yang didapatkan oleh Kahar dan Amin (1988) sebesar 4,78-6,17\%/hari. Begitu pula yang didapatkan oleh Pongsapan et al. (1995) hanya berkisar 1,67-2,04\%/hari. Hal ini disebabkan pada pendederan di tambak, selain makanan buatan juga masih dapat memanfaatkan makanan alami yang cukup baik bagi pertumbuhan dan kelangsungan hidup ikan bandeng serta memiliki jaminan kualitas air yang lebih baik daripada dalam bak-bak terkontrol. Menurut Rabanal (1967 dalam Anggoro 1984), makanan dan kualitas air termasuk komponen penentu dalam pertumbuhan benih ikan bandeng.

Meskipun secara statistik menunjukkan pengaruh yang tidak berbeda nyata di antara perlakuan, tetapi produksi biomassa tertinggi masih didapatkan pada perlakuan kepadatan 300 ekor/hari. $\mathrm{Hal}$ ini disebabkan tingkat kelangsungan hidup yang cukup tinggi (jumlah individu yang banyak) serta berat rata-rata individu tidak berbeda jauh dengan perlakuan lainnya.

Tambak tanah gambut merupakan tambak yang belum siap untuk memproduksi makanan alami yang baik bagi kebutuhan ikan bandeng dan udang, namun dengan penambahan makanan buatan yang cukup pada pendederan ikan bandeng dengan padat penebaran 100-300 ekor/hapa atau 200-600 ekor $/ \mathrm{m}^{3}$ masih memberikan pertumbuhan dan kelangsungan hidup yang cukup tinggi.

Rasio konversi pakan yang diperoleh pada percobaan ini masih lebih rendah daripada yang didapatkan oleh Lim et al. (1979) yaitu 1,96-2,46 dan Daud et al. 
(1995) sebesar 2,6-2,4. Hal ini antara lain karena dalam pendederan di tambak ini hewan uji masih dapat memanfaatkan makanan alami yang tersedia. Di samping itu, kondisi kualitas air masih mendukung bagi pertumbuhan ikan bandeng (Tabel 3 ).

Tabel 3. Nilai kualitas air yang didapatkan selama penelitian

Table 3. Water quality values during experiment

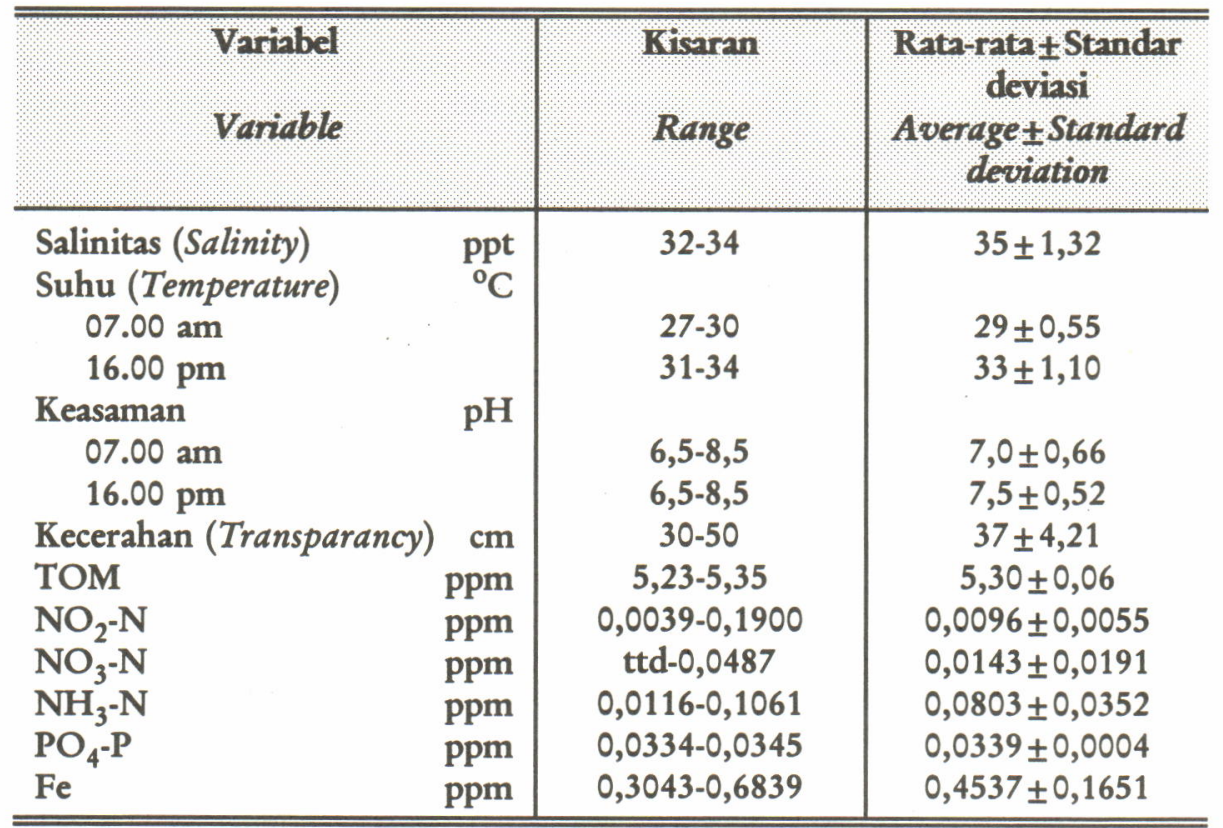

TOM = Total organic matter

\section{Kualitas Air}

Pada tambak tanah gambut, fluktuasi kualitas air sangat dipengaruhi oleh kualitas tanah yang kurang stabil, sehingga akan berakibat lanjut terhadap kondisi biologis ikan bandeng yang dipelihara. Kualitas air yang didapatkan selama penelitian pada tambak yang digunakan untuk pendederan bandeng terlihat pada Tabel 3.

Salinitas sebagai salah satu komponen sifat kimia air yang berperan dalam pengaturan osmoregulasi ikan menunjukkan nilai yang relatif tinggi. $\mathrm{Hal}$ ini terjadi karena penelitian ini berlangsung saat musim kemarau dan sumber airnya merupakan sungai mati sehingga hanya didominasi oleh air laut sebagai akibat pasang surut. Namun dengan pergantian air yang cukup baik, fluktuasi salinitas dapat dihindari sehingga benih ikan bandeng mampu menciptakan kondisi yang iso-osmotik. Menurut Schuster (1960), nener bandeng mempunyai 
kemampuan adaptasi terhadap salinitas yang cukup besar (euryhaline). Namun menurut Ranoemihardjo dan Padlan (1976), salinitas yang baik bagi kehidupan nener di petakan pendederan berkisar $20-30 \mathrm{ppt}$, dan di atas $45 \mathrm{ppt}$ pertumbuhan nener dapat terhambat.

Suhu air akan mempengaruhi laju metabolisme hewan akuatik. Menurut Lin (1969), untuk tumbuh dan hidup dengan normal benih ikan bandeng memerlukan suhu sekitar $23,7-33^{\circ} \mathrm{C}$. Hal ini menunjukkan bahwa rentang suhu selama percobaan $\left(27-34^{\circ} \mathrm{C}\right)$ masih cukup mendukung pertumbuhan benih ikan bandeng. Menurut Suhardjo (1994), tanah gambut sangat cepat panas dan lambat melepaskan panas sehingga mengakibatkan suhunya sangat bervariasi pada permukaan tanah. Namun karena volume air tambak cukup banyak, variasi suhu air dapat ditekan.

Derajat keasaman $(\mathrm{pH})$ air dengan kisaran 6,5-8,5 menunjukkan bahwa air media relatif bersifat sedikit asam hingga alkalis. Menurut Lin (1969), untuk dapat hidup dan tumbuh normal, benih ikan bandeng memerlukan media dengan $\mathrm{pH}$ 6,5-8,5. Meskipun salah satu ciri dari tanah gambut adalah $\mathrm{pH}$ rendah, namun dengan pengelolaan air yang baik, maka penurunan $\mathrm{pH}$ air dapat dikurangi. Menurut Vadari et al. (1992), dengan pengelolaan air yang menggunakan sumber air pasang pada reklamasi tanah sulfat masam potensial, hasilnya relatif lebih baik. Nilai $\mathrm{pH}$ tanah tidak turun dan kandungan besi bebas konsentrasinya kecil.

Tingkat kecerahan air sangat berpengaruh terhadap kesuburan perairan. Kecerahan air yang didapatkan selama penelitian (berkisar $30-50 \mathrm{~cm}$ ) relatif lebih tinggi dari pada yang disarankan oleh Kusnendar dan Sudjiharno (1984) yaitu sekitar $30-35 \mathrm{~cm}$. Hal ini disebabkan kepadatan plankton yang relatif rendah.

$\mathrm{NH}_{3}-\mathrm{N}$ dan $\mathrm{NO}_{2}-\mathrm{N}$ merupakan senyawa yang beracun terhadap benih ikan bandeng, namun konsentrasi selama penelitian masih dalam batas yang normal bagi pertumbuhan benih ikan bandeng. Menurut Boyd (1979), secara umum kehidupan ikan tidak terganggu pada media dengan konsentrasi $\mathrm{NH}_{3}-\mathrm{N}$ kurang dari $0,10 \mathrm{ppm}$, dan toksisitas $\mathrm{NH}_{3}-\mathrm{N}$ dalam air akan meningkat seiring dengan penurunan konsentrasi oksigen terlarut. Konsentrasi oksigen terlarut terendah didapatkan pada pukul 22.00 dan 02.00 dan tertinggi pada pukul 14.00 (Gambar 1). Fluktuasi harian oksigen terlarut yang cukup tinggi ini disebabkan terjadinya proses respirasi, dekomposisi, fotosintesis dan difusi. Namun kondisi ini masih dapat ditolerir oleh benih ikan bandeng.

Kandungan $\mathrm{NO}_{3}-\mathrm{N}$ dan $\mathrm{PO}_{4}-\mathrm{P}$ sebagai salah satu indikator kesuburan perairan masing-masing dari 0,0487 dan $0,0334-0,0345 \mathrm{ppm}$, menunjukkan bahwa perairan tersebut relatif kurang subur. $\mathrm{Hal}$ ini didasari atas pendapat Chu (1943) bahwa untuk menopang kehidupan dan pertumbuhan alga secara optimal dibutuhkan 0,090-1,800 ppm $\mathrm{PO}_{4}-\mathrm{P}$ dan $0,900-3,500$ ppm $\mathrm{NO}_{3}-\mathrm{N}$. Rendahnya kandungan $\mathrm{PO}_{4}-\mathrm{P}$ ini dapat disebabkan karena terikat menjadi besi 
dan aluminium fosfat, terpakai oleh fitoplankton, bakteri, sedimen, dan terlindi bersama air (Mustafa et al., 1994).

Dissolved Oxygen (ppm)

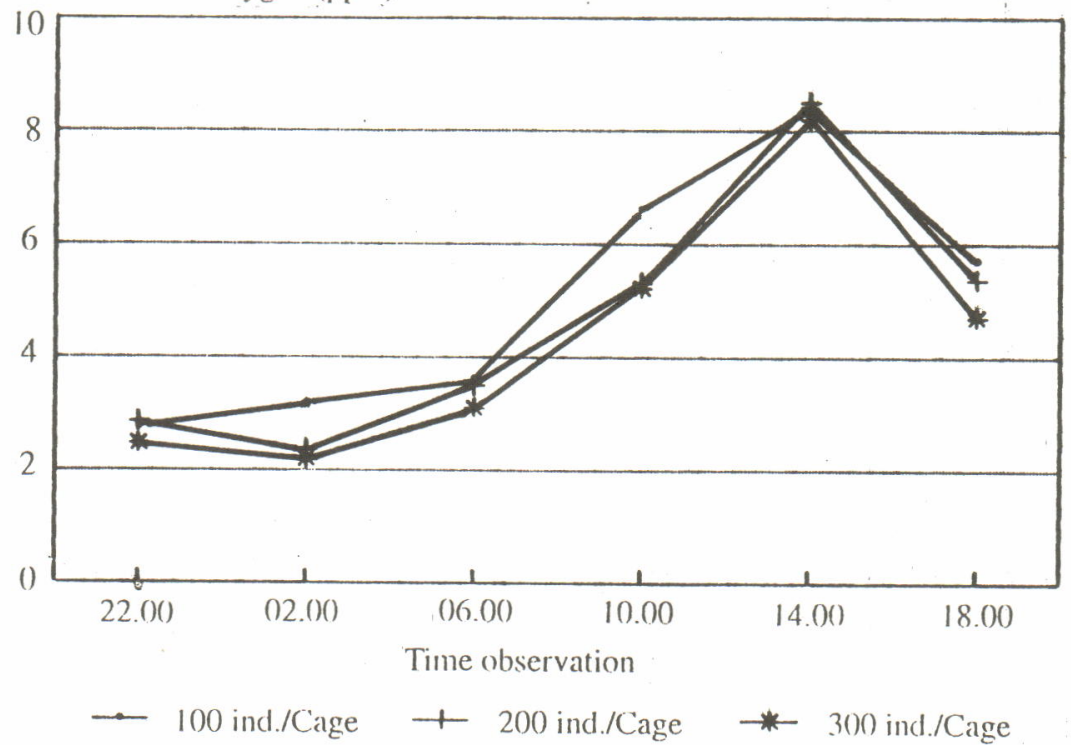

Gambar 1. Fluktuasi oksigen terlarut dalam tambak tanah gambut Figure 1. Dissolved oxygen fluctuation in peat soil brackishwater pond

Konsentrasi Fe sebesar 0,3043-0.6839 ppm, hampir sama dengan konsentrasi Fe yang didapatkan oleh Mustafa et al. (1994) pada tanah gambut yang direklamasi yaitu sebesar 0,2890-0,4390 ppm.

Jenis plankton yang ditemukan terdiri dari 3 genera fitoplankton dan 2 genera zooplankton yang termasuk ke dalam klas Bacillariophyceae, Cyanophyceae, Rotifera dan Crustacea. Kelimpahan plankton yang didapatkan sebanyak 182 ind./1 menunjukkan nilai yang sangat rendah bila dibandingkan dengan kelimpahan fitoplankton yang didapatkan oleh Atmomarsono (1992) pada tambak gambut di Pedes, Jawa Barat sebanyak 240.576 ind./1. Begitu pula indeks keaneka-ragaman dan indeks dominansi masing-masing 0,3914 dan 0,6086, menunjukkan kondisi perairan yang cukup labil sehingga rentan terhadap perubahan lingkungan yang mungkin terjadi. Namun bila dilihat dari jenis plankton yang dominan yaitu Oscillatoria sp (56,6\%) dan Rotifera (23,6\%), merupakan makanan alami yang sangat baik bagi ikan bandeng.

Berdasarkan hasil analisis bakteri dalam air, secara keseluruhan didapatkan 4 jenis bakteri patogen sebelum penebaran dan setelah panen (Tabel 4). Namun berdasarkan jumlah bakteri dalam tambak tersebut masih dalam kondisi yang 
normal. Hal ini didasari atas pendapat Atmomarsono et al. (1993) bahwa apabila jumlah bakteri yang mampu tumbuh pada media TCBSA telah melebihi $10^{3} \mathrm{CFU} / \mathrm{ml}$ air contoh dan didominasi oleh bakteri patogen, maka kondisi tersebut dapat menyebabkan kematian udang windu di tambak.

Tabel 4. Jenis dan jumlah bakteri (CFU/ml) dalam air tambak gambut bukaan baru

Table 4. Composition and number of bacteria (CFU/ml) of peat soil brackish water pond used for rearing milkfish for 20 days

\begin{tabular}{l|c|c|c|c}
\hline $\begin{array}{c}\text { Jenis bakteri } \\
\text { Kind of bacteria }\end{array}$ & $\begin{array}{r}\text { Awal } \\
\text { Initial }\end{array}$ & $\begin{array}{r}\text { Akhir } \\
\text { Final }\end{array}$ \\
\cline { 2 - 5 } & TSA & TCBSA & TSA & TCBSA \\
\hline Pseudomonas & $5,4 \times 10^{6}$ & - & - & - \\
Enterobacteriaceae & $6,0 \times 10^{5}$ & - & $1,38 \times 10^{5}$ & - \\
Acinetobacter & - & $1,70 \times 10^{2}$ & - & $1,0 \times 10^{3}$ \\
Aeromonas & - & $1,90 \times 10^{1}$ & $1,24 \times 10^{6}$ & - \\
\hline \hline
\end{tabular}

\section{Kualitas Tanah}

Kualitas tanah dapat berpengaruh langsung dan tidak langsung terhadap pertumbuhan dan kelangsungan hidup ikan bandeng. Kualitas tanah selama penelitian dapat dilihat pada Tabel 5.

Tabel 5. Kualitas tanah tambak tanah gambut pada awal dan akhir penelitian Table 5. Peat soil quality variables at the beginning and end of experiment

\begin{tabular}{l|c|c}
\hline $\begin{array}{c}\text { Variabel } \\
\text { Variable }\end{array}$ & $\begin{array}{c}\text { Awal } \\
\text { Initial }\end{array}$ & $\begin{array}{c}\text { Akhir } \\
\text { Final }\end{array}$ \\
\hline $\mathrm{pH}\left(\mathrm{H}_{2} \mathrm{O}\right)$ & 4,30 & 4,45 \\
$\mathrm{pH}(\mathrm{KCl})$ & 4,16 & 4,41 \\
Redox (mV) & 248 & 233 \\
C-organic (\%) & 8,02 & 9,02 \\
Organic matter (\%) & 13,83 & 15,55 \\
Fe (ppm) & 18,134 & 17,698 \\
$\mathrm{Al}(\mathrm{ppm})$ & 6,710 & 5,515 \\
$\mathrm{SO}_{4}(\mathrm{ppm})$ & 12,730 & 11,004 \\
$\mathrm{P}(\mathrm{ppm})$ & 0,0136 & nd \\
\hline \hline
\end{tabular}

$n d=$ not detectable 
Keasaman $(\mathrm{pH})$ tanah tambak gambut yang digunakan dalam penelitian ini tergolong sangat masam dengan kandungan bahan organik, $\mathrm{Fe}$ dan $\mathrm{Al}$ yang cukup tinggi, sementara ketersediaan fosfat sangat kecil. Sehingga secara umum kondisi tanah ini kurang mendukung bagi pertumbuhan benih ikan bandeng. Namun bila dihubungkan dengan kualitas air dan pertumbuhan benih ikan bandeng yang terjadi, nampaknya bahwa dengan pengelolaan air secara baik dan masa pemeliharaan yang relatif singkat, serta kepadatan organisme yang belum melampaui daya dukung lahan, maka kualitas tanah yang kurang mendukung belum banyak berpengaruh terhadap kualitas air dalam pendederan benih ikan bandeng.

\section{KESIMPULAN DAN SARAN}

Pendederan bandeng dengan kepadatan 300 ekor $/ 0,5 \mathrm{~m}^{3}$ pada tambak tanah gambut masih memberikan pertumbuhan normal dengan kelangsungan hidup yang cukup tinggi $(94,17 \%)$ serta produksi biomassa sebesar $80,35 \mathrm{~g}$, bila disertai dengan pengelolaan air yang baik.

Perlu penelitian padat penebaran yang lebih tinggi pada pendederan di tambak tanah gambut.

\section{UCAPAN TERIMA KASIH}

Diucapkan terima kasih kepada Saudari Dra. Rosiana Sabang, Reni Yulianingsih, Nurjanna dan Rifka Pasande, BSc. atas segala bantuannya dalam penganalisaan kualitas air, tanah, plankton dan bakteri pada penelitian ini.

\section{DAFTAR PUSTAKA}

Anggoro S., 1984. Pengaruh salinitas terhadap kuantitas dan kualitas makanan alami serta produksi biomasa nener bandeng. Tesis. Fakultas Pasca Sarjana, Institut Pertanian Bogor, Bogor. 109 hal.

Atmomarsono M., 1992. Faktor penduga kesuburan perairan pada tambak tradisional. J. Penelitian Budidaya Pantai 8(4):73-85.

Atmomarsono M., M.I.Madeali, A.Tompo dan Muliani, 1993. Bakteri penyebab penyakit pada udang windu di perairan tambak Sulawesi Selatan. Makalah dibawakan pada Simposium Perikanan I, Jakarta, 25-27 Agustus 1993. Balai Penelitian Perikanan Budidaya Pantai, Maros. 9 hal.

Boyd C.E., 1979. Water quality in warmwater fish pond. Craftmaster Print. Inc., Auburn. 359 p.

Chu S.P., 1943. The influence of the mineral and composition of the medium on the growth of phytoplankton and algae. Part II. The influence of the concentration of inorganic nitrogen and phosphat phosphorus. The Ecol. 31(2)1-19. 
Hakim N., M.Y.Nykpan, A.M.Lubis, S.G.Nugroho, M.R.Saul, M.A.Lubis, M.A.Diha, G.B.Hong dan H.H.Bailey, 1986. Dasar-dasar ilmu tanah. Universitas Lampung, Lampung. 488 hal.

Jufri, Darmansyah, Wardoyo dan I.Setyadi, 1994. Pengaruh dosis pakan harian terhadap pertumbuhan dan kelangsungan hidup benih bandeng, Chanos cbanos dalam hapa. J. Penelitian Budidaya Pantai 10(1):49-56.

Kahar dan M.Amin, 1988. Pengaruh berbagai padat penebaran terhadap pertumbuhan dan tingkat kematian nener dengan sistem terkontrol. Jurnal Penelitian Budidaya Pantai 4(2):22-26.

Kusnendar E. dan Sudjiharno, 1984. Budidaya bandeng dan udang di tambak dalam Pedoman Budidaya Tambak. Dirjen Perikanan, Departemen Pertanian, Jakarta. hal:112-156.

Lim C.S., Sukwahongs and F.P.Pascual, 1979. A Preliminary study on the protein requirement of Chanos chanos (Forskal) fry in a controlled environment. Aquaculture Department, Southeast Asian Fisheries Develop-ment Center. Aquaculture, 17:195-201.

Lin H.S., 1969. Some aspect of milkfish ecology. Rep. Fish Culture Res., Fish Series Chin-Am. Joint Commission on Rural Reconstruction 7:68-90.

Mustafa A., A.Hanafi dan B.Pantjara, 1993. Pengaruh berbagai dosis kapur pertanian terhadap kualitas tanah gambut. J.Penelitian Budidaya Pantai 9(4):109-120.

Mustafa A., A.Hanafi dan B.Pantjara, 1994. Pengaruh reklamasi terhadap kualitas tanah dan air tambak tanah gambut. J. Penelitian Budidaya Pantai 10(2):103-116.

National Research Council (NRC), 1977. Requirement of warmwater fishes. National Academic Sciences, Washington D.C. 78 p.

Pongsapan D.S., Rachmansyah dan N.N. Palinggi, 1995. Pengaruh frekuensi pemberian pakan terhadap pertumbuhan dan kelangsungan hidup benih ikan bandeng, Chanos chanos. Balai Penelitian Perikanan Pantai, Maros. 11 hal.

Ranoemihardjo B.S dan P.G.Padlan, 1976. Teknik pengelolaan peneneran bandeng (Chanos chanos Forskal). Pusat Penelitian Udang, LPPI, Jepara. 21 hal.

Ricker W.E., 1975. Computation and interpretation of biological statistics of fish populations. Bull. Fish. Res. Board Can. 191:382 p.

Rounsefell G.A. and W.H. Everhart, 1962. Fishery science its methods and applications. John Wiley \& Sons, Inc., New York-London. 444 p.

Schuster W.H., 1960. Synopsis of the biological data on milkfish, Chanos chanos Forskal, 1775. FAO, Fish Synopsis 4:1-6. 
Sedgwick R.W., 1979. Influence of dietary protein and energy on growth, food consumption and food conversion efficiency in Penaeus merguiensis de Man. Aquaculture 16:17-30.

Suhardjo H., 1994. Tanah gambut. Pusat Penelitian Tanah dan Agroklimat, Bogor. 2 hal.

Vadari T., H.Suwardjo, S.Kasdi, A.Sutono, I.Abas dan R.A.L.Kselik, 1992. Peranan pengelolaan air dalam usaha mereklamasi tanah sulfat masam potensial (Sulfic Hydraquent) di Unit Tatas, Kalimantan Tengah. Pembr. Pen. Tanah dan Pupuk (10):1-15. 